\title{
Origin of Thyroid C Cells: Clinical Interpretation
}

\author{
Stavroula A. Paschou Andromachi Vryonidou \\ Department of Endocrinology and Diabetes, Hellenic Red Cross Hospital, Athens, Greece
}

\section{Dear Editor,}

We are writing to comment on the very interesting review article 'On the origin of cells and derivation of thyroid cancer: C cell story revisited' by Nilsson and Williams recently published in European Thyroid Journal [1]. The authors collected and presented in a very comprehensive way research data from mouse studies which really change the current concept of the neural crest origin of thyroid C cells. According to these data, a unifying origin of all thyroid cells from the endoderm seems most possible. The findings are really fascinating from a developmental embryology point of view. From a clinical point of view, however, medullary thyroid carcinoma which derives from thyroid $\mathrm{C}$ cells behaves as a neuroendocrine tumor. There are no similarities between this carcinoma profile and other cancers from organs with traditional endoderm origin (gastrointestinal, lung, thyroid follicular cells etc.) [2]. Even neuroendocrine tumors that are found in the gut or lungs consist of cells with different characteristics than cancers deriving from cells with endodermal origin (colon adenocarcinoma, lung adenocarcinoma etc.). They present marked differences in clinical picture and course, too [3]. Of course, the knowledge gap in the embryonic development of thyroid $\mathrm{C}$ cells will only be solved by the highly respected basic scientists of the field. After all, newly discovered pathways during embryogenesis may lead to new treatment approaches for medullary thyroid carcinoma, which will be wonderful for the good of our patients.

\section{Disclosure Statement}

The authors declare that they have no conflict of interest.

\section{References}

1 Nilsson M, Williams D: On the origin of cells and derivation of thyroid cancer: $\mathrm{C}$ cell story revisited. Eur Thyroid J 2016;5:79-93.

2 Nozières C, Chardon L, Goichot B, BorsonChazot F, Hervieu V, Chikh K, Lombard-Bohas C, Walter T: Neuroendocrine tumors producing calcitonin: characteristics, prognosis and potential interest of calcitonin monitoring during follow-up. Eur J Endocrinol 2016; 174:335-341.

3 Rosai J: The origin of neuroendocrine tumors and the neural crest saga. Modern Pathology 2011;24:S53-S57.

\section{KARGER}

E-Mail karger@karger.com www.karger.com/etj
Andromachi Vryonidou, MD, $\mathrm{PhD}$

Department of Endocrinology and Diabetes Hellenic Red Cross Hospital, Athanasaki 1 GR-11526 Athens (Greece)

E-Mail mahi_vr@hotmail.com 